\title{
Review on Pre and Post Emergence Herbicides against Weeds, Yield Attributes and Yield of Onion
}

\author{
Nisha Jangre, Thakur Omesh*, C.R. Gupta and Preetesh Pandey \\ Department of Vegetable Science, India \\ *Corresponding author
}

\section{A B S T R A C T}

\begin{tabular}{|c|}
\hline Keywords \\
\hline $\begin{array}{l}\text { Onion, Pre and post } \\
\text { emeregence } \\
\text { herbicide, Cost } \\
\text { economics }\end{array}$ \\
\hline Article Info \\
\hline $\begin{array}{l}\text { Accepted: } \\
10 \text { March } 2018 \\
\text { Available Online: } \\
10 \text { April } 2018\end{array}$ \\
\hline
\end{tabular}

Weeds are undesirable plants out of place and function as an uneconomic tax on the crop by taking the space required for the plant, absorbing the water and nutrients from the soil and by competing for other essentials like light, moisture etc. There are two methods generally employed for controlling weeds. viz., (i) Hand weeding, and (ii) Use of herbicides. In India, the first one is generally practiced by the farmers. This method is the most labour intensive and costly. Due to the industrial development, the agricultural labourers are engaged towards the industries for higher wages. This migration creates the labour problems particularly during the critical periods of different cultural operations. To overcome this difficulty, with the recent introduction of new herbicides, chemical weed control has come to the forefront as an additional tool to fight weeds.

\section{Introduction}

Onion (Allium cepa L.) is one of the most important vegetable crops grown throughout the world. It is said to be native of Central Asia and Mediterranean region. It belongs to economically important family Alliaceae. Among the vegetable crops listed by FAO, onion is second in terms of annual world production. The major onion producing countries are China, India, USA, Turkey, Japan, Iran, Pakistan, Spain and Brazil.

Onion bulb and green leaves both are rich in minerals, protein and ascorbic acid. The pungency in onion odour is formed by enzymatic reaction only when tissues are damaged. The pungency in onion is due to volatile oil as allyl-propyl disulphide. The colour of the outer skin of onion bulbs is due to quercetin. Among the various constraints in onion production, weeds pose serious problem in its cultivation which reduce bulb yield to the extent of $40-80 \%$ (Singh et al., 1992 and Verma and Singh, 1997). The weeds infestation is problematic especially at early stage of crop growth. The inherent characteristic of onion crop such as short stature, non-branching habit, slow growth and shallow root system render it poor competitor 
with the weeds. Further problem is solved by excessive use of nutrients, use of farm yard manure and frequent irrigation.

Weeds are undesirable plants out of place and function as an uneconomic tax on the crop by taking the space required for the plant, absorbing the water and nutrients from the soil and by competing for other essentials like light, moisture etc. Weeds being much more hardy and tenacious than crops plants, if unchecked, get the upper hand and adversely affect the growth and yield of crop plant. There are two methods generally employed for controlling weeds. viz., (i) Hand weeding, and (ii) Use of herbicides. In this review a various experimental findings of different experiments covering important aspect of weed flora, losses caused by weeds and effect of weed management practices on crops, yield and yield attributes, use of chemical and cultural methods of weed management and economics is given below.

\section{Composition of weed flora and degree of their population}

The composition of weed flora and degree of their population in onion fields has been found to vary from place to place and even at the same place from year to year depending upon the agro climatic conditions and cultural practices.

Pandey (2000) reported that the major weed flora in onion consisted Galinsoga parviflora, Brachiaria ramosa, Cyperus rotundus, Cannabis sativa, Polygonum plebeium, Fumaria parviflora, Phalaris minor and Oxalis latifolia. Syed and Malik (2001) reported that the major weed flora in onion consisted Amaranthus hybridus, Convolvus arvensis, Cyprusrotundus Chenopodium album, Echinochola spp., Sophora alopecuroides were the most damaging.
Amrutkar et al., (2002) recorded that the major weed flora in onion consisted Cyperus rotundus, Cynodon dactylon, Dinebra retroflexa, Parthemium hysterophorus, Chenopodium album, Anagallis arvensis, Argemone maxicana, Physalis minima, Euphorbia geniculata, Lagasca mollis and Portulacea oleracea. Naresh et al., (2002) recorded the dominant weed flora associated with crop at Udaipur, which included Chenopodium album L., Chenopodium murale L., Amaranthus viridis L., Anagallis arvensis L., Convolvulus arvensis L., Parthenium hysterohorus L., Spergula arvensis L., Digera arvensis Fork., Cyperus rotundus, Trianthema portulacastrum, Euphorbia hirta and Cynodon dactylan L.

Sukhadia et al., (2002) recorded that the major weed flora in percentage at Junagarh during kharif season were Echinochloa colonum, (31\%), Eluropus villosus (10\%), Dactyloctenium aegytium (3\%), Digera arvensis (16\%), Phyllanthus nirusi (8\%), Cyperu rotundus (14\%) and Cyperus iria $(2 \%)$.

Ahuja et al., (2003) observed that the dominant weed species in the experimental field was Poa annua in both cabbage and onion crops and Cyperus rotundus in onion among the narrow-leaf weeds. Trianthema portulacastrum, Chenopodium spp., Trigonella polycerta [T. polyceratia], Medicago denticulata, Lepidium sativum and Anagallis arvensis in both cabbage and onion crops, Amaranthus spp. and Tribulus terrestris in onion among the broad-leaf weeds.

Husrev and Dogan (2003) observed the dominant weed species in the field experiment was Chenopodium album, Amaranthus retroflexus, Convolvulus arvensis, Heliotropium europaeum and Solanum nigrum. 
Rathore and Shekhawat (2004) reported that the major weeds in onion field at Ajmer during kharif were Amaranthus viridis, Cyperus rotundus, Cynodon dactylon, Digera arvensis, Eclipta alba, Fumria parviflora, Solanum nigrum, Trianthema monogyna, Xanthium strumarium. Dobrzanski (2004) recorded that the major weeds in onion were Chenopodium album, Galinsoga parviflora, Capsella bursa-pastoris, Sinapis arvensis, Thlaspi arvense, Lamium amplexicaule, Senecio vulgaris, Stellaria media, Fallopia convolvulus [Polygonum convolvulus], Polygonum persicaria, P. aviculare, Amaranthus retroflexus, Anthemis sp., Matricaria sp., Urtica urens, Galium aparine, Viola arvensis, Elymus repens, Echinochloa crus-galli and Poa annua.

Dobrzanski and Paczynski (2005) reported that the major weeds in onion are Chenopodium album, Galinsoga parviflora, Capsella bursa-pastoris, Sinapis arvensis, Thlaspi arvense, Urtica urens. Channappagoudar and Biradar (2007) observed that the major weeds in onion were Commelina benghalensis, Cyprus rotundus, Parthenium hiysterophorus, Phyllanthus niruri, Euphorbia geniculata and Dinebra retroflexa. Tariq et al., (2007) screened that the major weeds in onion were Phalaris minor, Cronopus didymus, Medicago denticulata, and Rumex dentatus.

\section{Effect of weed management practices on crop growth and development}

Singh and Singh (1993) showed that weed free treatment produced the maximum plant height, numbers of leaves plant ${ }^{-1}$, bulb diameter, fresh weight of bulb, dry weight of leaves, bulb and bulbs yield was however at par with pendimethalin and oxadiazon @ 1.5 $\mathrm{kg} \mathrm{ha}{ }^{-1}$ with one HW. Minimum value of crops parameters were recorded under weedy check control. Saikia et al., (1997) indicated that Fluchloralin $\left(0.5\right.$ or $\left.1.0 \mathrm{~kg} \mathrm{ha}^{-1}\right)$ alone or in combination with one HW (after 60 days) or HW (after 40 and 60 days) reduced weed dry weight significantly and improved onion plant growth and bulb development.

Ved et al., (2000) observed that Alachlor at @ $2.0 \mathrm{~kg} \mathrm{ha}^{-1}+\mathrm{HW}$ at 45 DAT being at par with pendimethalin at @1.5 kg ha ${ }^{-1}+\mathrm{HW}$ at 45 DAT and weed- free, proved to be the superior integrated weed control approach to control weeds and increased the plant height, bulb diameter and bulb weight. Nandal and Singh (2002) also reported that fluchloralin @ $1.0 \mathrm{~kg}$ in combination with one $\mathrm{HW}$ at 45 DAT proved to be the significantly superior in increasing the plant height and number of leaves per plant and remained at par with oxyfluorfen@0.15 kg ha ${ }^{-1}$ with one HW at 45 DAT.

Thakral et al., (2003) stated that the weed-free treatment provided the maximum number of total and healthy seedlings. Among the herbicidal treatments, trifluralin at @ $1.00 \mathrm{~kg}$ $\mathrm{ha}^{-1}$ as pre-sowing soil incorporation, pendimethalin at @ $1.00 \mathrm{~kg} \mathrm{ha}^{-1}$ and alachlor at@2.00 kg ha ${ }^{-1}$ applied as pre-emergence were the most effective herbicides for controlling weeds and producing healthy seedlings. Ghaffoor (2004) observed that Swat-I was superior in terms of the number of leaves plant ${ }^{-1}$, length of leaves, number of bulbs plot ${ }^{-1}$, bulb diameter, weight of bulbs and bulb yield. The herbicides significantly controlled the weeds.

\section{Effect of weed management practices on Yield and yield attributes}

Pandey et al., (1992) also obtained maximum bulb yield of onion with oxadiazon @ $0.75 \mathrm{~kg}$ ha $^{-1}$. Low dry matter accumulation by weeds and higher weed control efficiency resulted in larger size bulb which ultimately resulted in higher yield under pre-emergence application 
of either oxadizon @ $0.75 \mathrm{~kg} \mathrm{ha}{ }^{-1}$ or oxyfluorfen@0.24 kg ha ${ }^{-1}$ along with one HW at 40 DAT as well as conventional practice of two HW at 20 and 40 DAT and proved its superiority over remaining treatments resulting in 459, 380 and 372 per cent higher bulb yield over the unweeded control.

Sandhu et al., (1993) observed that all weed control treatments reduced weed DW from untreated control values of $3350-4030 \mathrm{~kg} \mathrm{ha}^{-1}$ to $330-1240 \mathrm{~kg} \mathrm{ha}^{-1}$ and increased onion bulb yields from $3030-8570 \mathrm{~kg} \mathrm{ha}^{-1}$ to 14760 $22460 \mathrm{~kg} \mathrm{ha}^{-1}$. Pendimethalin at $0.75 \mathrm{~kg}$ resulted in the greatest crop yields.

Singh and Singh (1993) observed that oxyfluorfen@1.0 kg ha ${ }^{-1}$ with one HW at 50 DAT (295.70 q ha ${ }^{-1}$ ) when applied at higher rate gave significantly better yield than applied at lower rate but this is not true in case of trifuralin and alachlor where, nonsignificant increase was observed.

Porwal (1995) reported that superiority of pendimethalin in controlling weeds in garlic resulting in increased yield of bulbs. Similarly, Sandhu et al., (1993) also opined out similar results of pendimethalin and fluchloralin in onion and garlic.

Saikia et al., (1997) screened that Fluchloralin $\left(1.0 \mathrm{~kg} \mathrm{ha}^{-1}\right)+$ one HW at 40 DAT resulted in the greatest bulb yield $\left(16.9 \mathrm{t} \mathrm{ha}^{-1}\right)$, followed by the weed-free treatment $\left(16.0 \mathrm{t} \mathrm{ha}^{-1}\right)$.

Verma and Singh (1997) found that weed population and weed dry weight $\mathrm{m}-2$ were lowest in plot treated with@ $1.5 \mathrm{~kg} \mathrm{ha}^{-1}$ pendimethalin in onion. Yadiraju and Ahuja (1999) showed that post-emergence application of fluchloralin @ $0.9 \mathrm{~kg} \mathrm{ha}^{-1}$, oxadiazon@0.75 kg ha ${ }^{-1}$ and oxyfluorfen @ $0.24 \mathrm{~kg} \mathrm{ha}^{-1}$ at 25 DAT gave lower bulb yield and remained at par with unweeded control.
Pandey (2000) also recorded the maximum yield of bulb (227.76 q ha $\left.{ }^{-1}\right)$ with application of pendimethalin@1.0 kg ha ${ }^{-1}$ which was significantly higher as compared to the yield obtained under weed check (163.22 q ha $\left.{ }^{-1}\right)$.

Yadav et al., (2000) reported from Hisar that weed free treatment recorded the higher bulb yield of $323.45 \mathrm{q} \mathrm{ha}^{-1}$ which was statistically at par with pendimethalin @ $1.5 \mathrm{~kg} \mathrm{ha}^{-1}$. However, the highest net income and yield of bulbs was recorded with the application of oxyfluorfen@0.15 kg ha ${ }^{-1}$ closely followed by pendimethalin @ $1.5 \mathrm{~kg} \mathrm{ha}^{-1}$ due to effective control of weeds during critical period of crop-weed competition.

Kolhe (2001) recorded that Pre-emergence application of oxyfluorfen @ $0.15 \mathrm{~kg} \mathrm{ha}^{-1}$ supplemented with one $\mathrm{HW}$ at 35 DAT was equally effective to that of two $\mathrm{HW}$ at 20 and 35 DAT in alleviating weed competition and bulb yield in the range of 159.36-447.25 per cent was observed due to adoption of weed management practices.

Nandal and Singh (2002) recorded the highest bulb yield (304.43 q ha ${ }^{-1}$ ) and net returns (Rs $60196 \mathrm{ha}^{-1}$ ) with the application of oxyfluorfen $\left(0.25\right.$ a.i. $\left.\mathrm{kg} \mathrm{ha}^{-1}\right)+\mathrm{HW}$ at 40 DAT. The lowest weed density at all the stages of crop growth was observed under oxyfluorfen (0.37 a.i. $\left.\mathrm{kg} \mathrm{ha}^{-1}\right)$.

Ramachandraprasad et al., (2002) reported the highest bulb yield in the weed free plot $(15.4 \mathrm{t}$ $\mathrm{ha}^{-1}$ ), which was equivalent with those in the herbicide treatments, except fluchloralin.

Ghaffoor (2004) observed that plots treated with pendimethalin at 3 litres/ha gave the highest yield (40.28 $\mathrm{t} \mathrm{ha}^{-1}$ ) and weight of bulbs (127.9 g).

Priyadharshini and Anburani (2004) screened that pendimethalin + mulching treatments had 
the lowest weed population $(68 \mathrm{~m}-2)$ and weed dry matter (205 $\mathrm{g} \mathrm{m}-2)$ and the highest onion bulb yield $\left(25.51 \mathrm{t} \mathrm{ha}^{-1}\right)$.

Rathore and Shekhawat (2004) reported that fluchloralin applied @ $1.0 \mathrm{~kg} \mathrm{ha}^{-1}$ as preplanting incorporation in combination with one $\mathrm{HW}$ at 45 DAT proved to be most effective to control the weeds giving maximum weed control efficiency $(92.56 \%)$ and bulb yield (121.42 q ha ${ }^{-1}$ ) of kharif onion.

Marwat et al., (2005) recorded the maximum weeds kill percentage $(88.6 \%)$, size of onion bulbs $(78.25 \mathrm{ml})$, onion diameter $(5.49 \mathrm{~cm})$ and onion yield $\left(29950 \mathrm{~kg} \mathrm{ha}{ }^{-1}\right)$ in pendimethalin treatment, unlike the weedy control which recorded $00.0 \%, 47.75 \mathrm{ml}, 4.06$

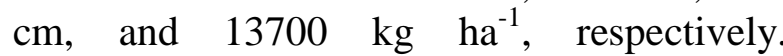
Therefore, pendimethalin is recommended at $1.32 \mathrm{~kg} \mathrm{ha}^{-1}$ for significantly reducing weed population and enhancing the bulb yield in onion.

Nargis et al., (2006) reported that weedicides applied at the pre-emergence stage, significantly controlled the weed population.

However, the 3.0 litre pendimethalin $\mathrm{ha}^{-1}$ treated plots gave the highest yield $(40.28 \mathrm{t}$ $\mathrm{ha}^{-1}$ ) and bulb weight (127.90) and was superior to other herbicidal treatments in increasing length, diameter, weight and yield of bulb.

Tariq et al., (2007) reported that herbicide treatments followed by hoeing except metribuzin gave bulb yield at par with weed free treatment. Metribuzin resulted in minimum bulb yield $(0.59 \mathrm{t}$ ha -1$)$ because of its extreme phytotoxicity to garlic crop, which resulted in the survival of a few plants. Pendimethalin in combination with manual hoeing gave the highest bulb yield and monetary returns.

\section{Effect of chemical and cultural methods of weed management}

Singh et al., (1992) studied weed control in onion cv. Pusa Red growing on a moderately fertile soil at Karnal (Haryana) following application of pendimethalin @ 1.0, 1.5 or 2 $\mathrm{kg} \mathrm{ha}{ }^{-1}$ after transplanting of seedling in January 1990. The persistence of pendimethalin was determined in onion plants and soil. Pendimethalin residues in the soil persisted up to 45 days when applied @ 1.0 $\mathrm{kg} \mathrm{ha}^{-1}$ pendimethalin and in onion plants varied from 11-15 days.

Sandhu et al., (1997) reported that pendimethalin 30 EC @ $2.5 \mathrm{~kg}$ and $1.87 \mathrm{~kg}$ $\mathrm{ha}^{-1}$ and fluchloralin 45 EC @ $2.5 \mathrm{~kg}$ and 1.87 $\mathrm{kg} \mathrm{ha}{ }^{-1}$ supplemented with one hoeing conducted after 105 days of sowing resulted in significant increase in bulb yield comparable to weed control.

Oliveria et al., (1997) reported that application of oxyfluorfen should be made at the time when weeds are still susceptible but the onion crop has become sufficiently tolerant to the herbicides. Singh et al., (1997) screened that $0.37 \mathrm{~kg}$ Oxyfluorfen was the most effective treatment for reducing population of Poa anпua, Coronopus didymus, Rumex acetosella and Medicago denticulate, with $0.25 \mathrm{~kg}$ Oxyfluorfen + hand weeding next best. None of the treatments gave season-long reductions in Cyperus rotundus populations. Vanhala et al., (1998) studied the effects of physical weed control measures (hoeing, flaming once or 3 times, and hand weeding) on carrot (cv. Fontana) and onion (cv. Sturon) quality during 1992-94 at 2 locations in Finland. Weed free plots were maintained with prometryn $1 \mathrm{~kg} \mathrm{ha}^{-1}+$ hand weeding. In onion, weedy plots resulted in the lowest marketable yield. However, repeated flaming, although providing the best weed control, inhibited onion development 
resulting in poorer quality onion as compared with a single flaming treatment and hand weeding.

Ramachandraprasad et al., (2002) noted the lowest weed population with oxyfluorfen at $0.12 \mathrm{~kg} \mathrm{ha}^{-1}$. The highest weed control efficacy was obtained with oxyfluorfen at $0.06 \mathrm{~kg} \mathrm{ha}^{-1}+\mathrm{HW}$, followed by metolachlor $+\mathrm{HW}$.

Sukhadia et al., (2002) reported that to manage weed problem, Oxidiazon at $0.75 \mathrm{~kg}$ $\mathrm{ha}^{-1}$ or Oxyfluorfen at $0.24 \mathrm{~kg} \mathrm{ha}^{-1}$ as preemergence application along with one $\mathrm{HW}$ at 40 DAT as well as conventional practices of two HW proved to the most effective.

Ahuja et al., (2003) reported that oxyfluorfen @ $0.16 \mathrm{~kg} \mathrm{ha}^{-1}$, pendimethalin@0.75 kg ha ${ }^{-1}$ and metribuzin@0.70 kg ha ${ }^{-1}$ significantly reduced the weed population and dry weight accumulated at 45 DAT cabbage and at harvest time of relay crop onion and increased the onion yield which was comparable to weeded control.

Dubey et al., (2005) also noticed the maximum yield in pendimethalin @ $1.0 \mathrm{~kg}$ $\mathrm{ha}^{-1}$ (PE) at 30 DAT (sand mix) in transplanted onion var. N-53 at NRC, Jabalpur (M.P). Hence, the sequential application of pendimethalin is more effective as compared to single dose.

Qasem (2005) reported that oxadiazon@ 0.75 $\mathrm{kg} \mathrm{ha}^{-1}$ and oxyfluorfen@ $0.6 \mathrm{~kg} \mathrm{ha}^{-1}$, both applied as pre sowing and post-emergence in onion seedlings resulted in the highest seedlings yield and the lowest weed biomass.

Chopra and Chopra (2006) reported that all the weed control treatments significantly reduced the weed density and dry weight of weeds, and in turn increased the bulb yield compared with weedy check.
Channappagoudar and Biradar (2007) observed that pendimethalin in combination with one HW recorded the lowest weed biomass. Tiwari et al., (1999) also observed sharp decline in weed biomass when preemergence application of herbicides was supplemented with one hand weeding in onion.

\section{Economics of weed management in onion}

Saikia et al., (1997) observed the maximum cost-benefit ratio $(1: 1.27)$ was obtained with Fluchloralin $\left(1.0 \mathrm{~kg} \mathrm{ha}^{-1}\right)+\mathrm{HW}$, Fluchloralin $\left(0.5 \mathrm{~kg} \mathrm{ha}^{-1}\right)+\mathrm{HW}$ was more cost-effective than the weed-free treatment, due to reduced production costs. Unweeded plots led to a loss of 1662.97 Rs ha ${ }^{-1}$.

Nadagonda et al., (1998) also noted that pendimethalin@0.75 and $1.0 \mathrm{~kg} \mathrm{ha}^{-1}$ resulted in higher benefit: cost ratio than the unweeded control in onion. Singh and Singh (2000) obtained the maximum net profit with treatments pendimethalin@1.5 kg ha ${ }^{-1}$ and pendimethalin@1.5 kg ha ${ }^{-1}$ with one HW at 45 DAT in onion.

Ved et al., (2000) reported that alachlor at 2.0 $\mathrm{kg} \mathrm{ha}^{-1}+\mathrm{HW}$ at 45 DAT being at par with pendimethalin at $1.5 \mathrm{~kg} \mathrm{ha}^{-1}+\mathrm{HW}$ at $45 \mathrm{DAT}$ and weed-free, proved to be the superior integrated weed control approach to control weeds and also recorded high additional net returns.

However, the highest additional returns per rupee invested were obtained with alachlor at $2.0 \mathrm{~kg} \mathrm{ha}^{-1}$.

Ramachandraprasad et al., (2002) reported the highest net return with metolachlor @ $0.75 \mathrm{~kg}$ ha $^{-1}+$ one HW (Rs. 52007 ha $^{-1}$ ), followed by oxyfluorfen@0.06 kg ha ${ }^{-1}$ + one HW (Rs. 50 $240 \mathrm{ha}^{-1}$ ) and metolachlor@ $2 \mathrm{~kg} \mathrm{ha}^{-1}$ (Rs. 48 $896 \mathrm{ha}^{-1}$ ). 
Sukhadia et al., (2002) observed that transplanting proved better than broadcast to manage weed problem. Application of oxadiazon@ $0.75 \mathrm{~kg} \mathrm{ha}^{-1}$ or oxyfloufen@ $0.24 \mathrm{~kg} \mathrm{ha}^{-1}$ as pre-emergence application along with one HW at 40 DAT or 40 DAS as well as conventional practice of $2 \mathrm{HW}$ at 20 and 40 DAT/DAS proved most effective efficient and economic at Gujarat in onion crop.

Rathore and Shekhawat (2004) reported that application of fluchloralin in combination with HW at 45 DAT resulted in net returns (Rs $28097 \mathrm{ha}^{-1}$ ). Application of oxyfluorfen resulted in the highest benefit: cost ratio (11:63).

Chopra and Chopra (2006) reported maximum additional monetary returns and net monetary returns by oxyflurofen $0.15 \mathrm{~kg} \mathrm{ha}^{-1}$ integrated with one $\mathrm{HW}$ at 35 DAT and oxyfluorfen $0.30 \mathrm{~kg} \mathrm{ha}^{-1}$, respectively.

Channappagoudar and Biradar (2007) studied the economic analysis of weed management practices and indicated that pre-emergence application of pendimethalin @ $1.0 \mathrm{~kg} \mathrm{ha}^{-1}$ supplemented with one HW gave the highest net return of Rs. 51,296 with maximum B: C ratio of 8.77 .

\section{References}

Ahuja, S., Sandhu, K.S. and Ahuja, S. 2003. Weed management through the use of herbicides in cabbage-onion relay cropping system. Annuals of Biology 19 (1): 27-30.

Amrutkar, S.D., Patil, B.M., Karunakar, A.P. and Jiotode, D.T. 2002. Effect of various herbicides on yield and uptake of nutrients in onion (Allium cepa L.). Research on Crops 3: 695-661.

Channappagoudar and Biradar 2007. Physiological studies on weed control efficiency in direct sown onion. Karnataka Journal Agricultural Science 20(2): 375-376.

Chopra, N. and Chopra, N.K. 2006. Production of weed free mother bulb of onion (Allium cepa L.) through integration of herbicides and weeding. Indian Agricultural Research Institute.

Dobrzanski, A. and Paczynski, J. 2005. The problem of weeds and weed management in onion.

Dobrzanski, A. 2004. The problem of weeds and weed control management in onion. Nowosci and Warzywwnicze 38: 43-52.

Dubey, R.P., Moorthy, B.T.S. and Yaduraja, N.T. 2005. Chemical weed control in transplanted onion. In Proceeding of National Biennial conference, ISWS, PAU, April 6-9: 259-260.

Ghaffoor, A. 2004. Integrated weed management in different varieties of onion (Allium cepa L.). Pakistan Journal of Weed Science Research 10 (1/2): 5 .

Husrev, M. and Dogan, I. 2003. Invasive weed species in onion production system. Pak. J. Bot. 35(2): 155-160.

Kolhe, S.S. 2001. Integrated weed management in onion (Allium cepa L.). Indian Journal of Weed Science 33 (1/2): 26-29.

Marwat, K.B., Bakhtiar, Gul, Muhammad, Saeed and Zahid, Hussain 2005. Efficacy of different herbicides for controlling weeds in onion in higher altitues. Pakistan Journal of Weed Science 11(1/2): 61-68.

Nadagonda, B.T., Honyal, S.C., Malabasari, T.A., Patter and Ackin, C.G. 1998. Economics of weed control in drill sown onion. World Weed V: 131-134.

Nandal, T.R. and Singh, R. 2002. Integrated weed management in onion (Allium cepa L.) under Himachal Pradesh conditions. Indian Journal Weed Science. 34 (1\&4):72-75. 
Naresh, K., Maurya, I.B. and Intodia, S.K. 2002. Integrated weed management in onion (Allium cepa L.) seed crop in Vertisols of south Rajasthan. Vegetable science 29 (2):191-192.

Nargis, B., Jilani, M.S., Kashif, W. 2006. Integrated weed management in different varieties of onion. Indus Journal of Biological Sciences 3(1): 678-684.

Nowosci and Warzywwnicze 40: 37-51.

Oliveira, R.S. De, J.R., Silva, J.F.D.A. and Farrira, L.R. 1997. Revista Ceres, 44:116.

Pandey, R.P., Shuka, N. and Tiwari, J.P. 1992. Efficacy of herbicidal weed control onion (Allium cepa L.). Indian Journal of Weed Science 24 (1\&2): 1884.

Pandey, U.B. 2000. National Symposium on onion and garlic, production and postharvest management, challenges and strategies, Nov. 19-21, 2000 Abst. pp. 43-48.

Porwal, M.K.1995. Integrated weed management in garlic (Allium sativum) under vertisols. Indian Journal of Weed Science 27 (1\&2):16-18.

Priyadharshini, H.V. and Anburani, A. 2004. Efficiency of integrated weed management on weed control in onion (Allium cepa L. var. aggregatum) cv. Gnanamedu Local. Indian Journal of Weed Science 36(1/2): 155-156.

Qasem, J.R. 2005. Chemical weed control in seedbed sown onion (Allium cepa L.). Crop Protection 25 (6): 618-622.

Ramachndraprasad, T.V., Shekar, B.G., Kenchaiah, K. 2002. Weed management in transplanted onion under proctective irrigated situation. Indian Journal of Weed Science 34 (3/4): 327-328.

Rathore, B.S. and Shekhawat, B.S. 2004. Integrated weed management in kharif onion (Allium cepa L.) under semi-arid conditions. Haryana Journal of Agronomy 20 (1): 86-87.

Saikia, S., Saikia, A., Shadeque, A. and Gogoi, S. 1997. Integrated weed management in onion (Allium cepa L.). Annals of Biology Ludhaina 13 (1): 139-143.

Sandhu, K.S., Singh, D., Singh, J., and Saimbhi, M.S.1993. Studies on integrated weed management in onion (Allium cepa L.). Integrated Weed Management for Sustainable Agriculture Proceeding of an Indian Society of Weed Science International Symposium 3: 199-201.

Sandhu, K.S., Singh, D.T. and Singh, J.W. 1997. Weed management in garlic under Punjab conditions. Vegetable Science 24 (1): 7-9.

Singh, M.P. and Singh, K.P. 1993. Effect of weed control treatments on growth and yield of kharif onion cv. Agrifound Dark Red. Haryana Journal of Horiculture Science 22(3): 228-234.

Singh, S. and Singh, J. 2000. National Symposium on onion and garlic, production and post-harvest management challenges and strategies, Abst. p.226.

Singh, S.J., Sinha, K.K. Mishra, S.S., Thakur, S.S and choudhary, N.K. 1992. Study on weed management in onion (Allium cepa L.). Indian Journal of Weed Science 24: 6-10.

Singh, V., Bisen, R.K. and Agrawal, H.P. 1997. A note on weed control studies in onion. Vegetable Science 24 (2): 162163.

Sukhadia, N.M., Ramani, B.B. and Dudhatra. 2002. Response of rainy season onion (Allium cepa L.) to sowing methods and weed management practices. Indian Journal of Agronomy 47(2): 278-283.

Syed, W.H. and Malik, M.F. 2001. Efficacy of cultural and chemical weed control in 
transplanted onion. Agriculture research Institute 1(9): 825-827.

Tariq, M., Khalid, M.K. and Shakeel, M. 2007. Integrated weed management practices in garlic crop in Pakistan. Crop Protection 26 (7): 1031-1035.

Thakral, K.K., Yadav, S.P.S., Kharana, S.C. and Nehra, B.K. 2003. Herbicidal control of weeds in onion nursery production. Haryana Agricultural University Journal of Research 33(2): 107-111.

Vanhala, P., Hagg, M., Ahvarainen, R.A.M. and Tilikkala, K. 1998. Effects of physical weed control on carrot and onion quality. Agri. Food Quality II p. 218-221.

Ved, P., Pandey, A.K., Singh, R.D. and Mani, V.P. 2000. Integrated weed management in winter onion (Allium сера L.) under mid-hill conditions of north-western Himalayas. Indian Journal of Agronomy 45(4): 816-821.

Verma, S.K. and Singh, H.T. 1997. Effect of weed control measures and fertility on growth and productivity of rainy season onion (Allium cepa). Indian Journal of Agronomy 42: 540-543.

Verma, S.K. and Singh, T. 1996. Weed control in kharif onion (Allium cepa L.). Indian Journal of Weed Science 28: 4851.

Yadav, S.P.S., Thakaral, K.K., Yadav, A. and Sanwal, S.K. 2000. Economics of weed control with herbicides in onion. Haryana Journal of Agronomy 16 (1\&2): 113-116.

Yadiraju, N.T. and Ahuja, K.N. 1999. Weed control in onion (Allium cepa L.) through herbicides. Weed Science 31 (3): 253-254.

\section{How to cite this article:}

Nisha Jangre, Thakur Omesh, C.R. Gupta and Preetesh Pandey. 2018. Review on Pre and Post Emergence Herbicides against Weeds, Yield Attributes and Yield of Onion. Int.J.Curr.Microbiol.App.Sci. 7(04): 1222-1230. doi: https://doi.org/10.20546/ijcmas.2018.704.136 